\title{
Enabling autocracy? Peacebuilding and post-conflict authoritarianism in the Democratic Republic of Congo
}

Article

Accepted Version

von Billerbeck, S. and Tansey, O. (2019) Enabling autocracy? Peacebuilding and post-conflict authoritarianism in the Democratic Republic of Congo. European Journal of International Relations, 25 (3). pp. 698-722. ISSN 1460-3713 doi: https://doi.org/10.1177/1354066118819724 Available at https://centaur.reading.ac.uk/72718/

It is advisable to refer to the publisher's version if you intend to cite from the work. See Guidance on citing.

To link to this article DOI: http://dx.doi.org/10.1177/1354066118819724

Publisher: Sage

All outputs in CentAUR are protected by Intellectual Property Rights law, including copyright law. Copyright and IPR is retained by the creators or other copyright holders. Terms and conditions for use of this material are defined in the End User Agreement.

www.reading.ac.uk/centaur 
Central Archive at the University of Reading

Reading's research outputs online 


\title{
Enabling Autocracy? \\ Peacebuilding and Post-Conflict Authoritarianism in the Democratic Republic of Congo
}

\author{
Sarah von Billerbeck and Oisín Tansey
}

\begin{abstract}
Does peacebuilding shape the regime type of countries where international missions are deployed? Most peacebuilding missions take place in authoritarian contexts, and seek to overcome the legacies of conflict by overseeing transitions to democratic rule; however, most regimes that experience peacebuilding still retain some form of authoritarian rule. In this paper, we examine the extent to which international peacebuilding missions contribute to the consolidation of post-conflict authoritarian regimes even when their stated aims involve the promotion of democracy. We argue that international peacebuilders can act as enablers of authoritarianism in host countries. We distinguish this category of behavior from explicit 'autocracy promotion,' which implies intentional support to autocracy. Instead, enabling is often an unintended consequence, and we identify two mechanisms through which enabling occurs: by building the capacity of incumbent authoritarian leaders and by signaling a permissive environment for authoritarian behavior for national actors. We illustrate our argument with the case of the UN peacekeeping operation in the Democratic Republic of Congo.
\end{abstract}

\section{Introduction}

Does peacebuilding shape the regime type of countries where international missions are deployed? Most peacebuilding missions take place in authoritarian contexts, and seek to help overcome the legacies of conflict by overseeing transitions to democratic rule. Yet despite these efforts, most regimes that experience peacebuilding retain some form of authoritarian rule (Toft, 2010; Zürcher et al., 2013). In this paper, we examine the ways in which international peacebuilding missions contribute to post-conflict authoritarianism even when their stated aims involve the promotion of democracy.

Our analysis builds upon a range of scholarship that has explored the political trajectories of post-conflict regimes, but that has yet to adequately address the relationship between peacebuilding and authoritarianism. ${ }^{1}$ Scholarship on why post-conflict regimes consolidate authoritarian rather than democratic governance has to date focused on domestic features of the society in question, including levels of economic development, the nature of the conflict, and the kind of political institutions established once the conflict ends (Fish and Kroenig, 2006; Reilly, 2001; Reynolds, 2010; Sambanis, 2000). More recent scholarship has examined the impact of peacebuilding missions, but has offered conflicting results and is characterized by a problematic democracy bias (Fortna and Huang, 2012; Joshi, 2010; Steinert and Grimm, 2015). Indeed, it has focused principally on the ways in which peacebuilding can contribute to democratic rule, but

\footnotetext{
${ }^{1}$ Note that we use the term peacebuilding to refer to multidimensional peacekeeping, in order to distinguish it from 'traditional' peacekeeping, which is characterized by limited mandates that usually have little interest in or impact upon regime type or governance.
} 
there is rarely any in-depth discussion of the causal mechanisms linking peacebuilding missions to authoritarian outcomes. Furthermore, with few exceptions the scholarship on post-conflict political transitions has tended to ignore the recent and vibrant literature on the politics of authoritarian rule (Art, 2012; Brownlee, 2007; Svolik, 2012). As a result, the relationship between peacebuilding and authoritarianism has to date been under-theorized.

We seek to address this imbalance and examine the ways in which international peacebuilding contributes to authoritarian politics in post-conflict settings. We do not argue that international peacebuilders act as promoters of authoritarianism, but rather that as enablers, through both actions and inactions that provide material and informational relief to autocratic incumbents. Building on recent scholarship on authoritarianism, we identify two causal mechanisms through which international peacebuilders can bolster authoritarianism. First, by offering aid and assistance to individual ruling elites and by strengthening key institutions of the state, they can contribute to the state's authoritarian capacities. Second, despite having a mandate to promote democracy, peacebuilders often refrain from robustly condemning or punishing authoritarian forms of behavior for fear of threatening existing relationships and endangering stability. In doing so they send signals to regime elites that lower the perceived costs of nondemocratic behavior and widen opportunity structures for authoritarian rule.

To illustrate these dynamics, we examine the case of the United Nations (UN) peace operation in the Democratic Republic of Congo (DRC). Under the leadership of Joseph Kabila and the oversight of the UN mission, DRC has achieved some progress towards peace and stability. Yet despite embracing electoral politics it has failed to consolidate genuine democratic rule and the regime has turned increasingly authoritarian. Elections scheduled for 2016 have been repeatedly postponed, and Kabila's rule has contributed to the rise of societal polarization, mass protests, and generalized political instability (Stearns 2017). Of course, it is likely that DRC would have struggled to democratize with or without the presence of a UN mission (Bermeo, 2003; Bernhard et al., 2003). At the time of the UN's deployment, it lacked many of the conditions usually associated with democratic rule, such as economic wealth, a history of democracy, or a robust civil society. Consequently, we do not argue that the UN mission prompted the emergence of authoritarianism where democracy would otherwise have flourished. Rather, our aim is to identify how UN peacebuilders contributed to authoritarianism in DRC since 2003, and we argue that the current regime in DRC evolved as a result of both international and domestic action. ${ }^{2}$

The article proceeds as follows. First, we offer a critical review of the literature on postconflict political development, identifying important flaws with existing approaches. Second, we identify the key pillars of authoritarian rule, and outline the two causal mechanisms of UN enabling. Third, we outline our research design. We then turn to the case study of DRC, examining how the UN mission enhanced the institutional and coercive capacity of the state and expanded the political opportunity structures of the Kabila regime.

\footnotetext{
${ }^{2}$ We examine the period from 2003, when the conflict in Congo formally ended, until the present. The mission was first known as the Mission de l'Organisation des Nations Unies en Congo (MONUC) from 1999-2010 and subsequently as the Mission de l'Organisation des Nations Unies pour la Stabilisation en RD Congo (MONUSCO) from 2010-present.
} 


\section{Civil Conflict and Authoritarian Rule}

International peacebuilders invariably have to grapple with the politics of authoritarianism. ${ }^{3}$ Civil conflict is more likely to break out in authoritarian settings, which in turn also create the conditions for conflict recurrence (Toft, 2010: 24). Conflict tends to erode some of the core bases of democracy, including inter-community trust, economic development, and the presence of a burgeoning middle class (Bermeo, 2003; Jarstad and Sisk, 2008; Reynolds, 2010). Instead, conflict frequently contributes to conditions conducive to authoritarianism, as moderates are pushed to the margins and violent groups assume positions of authority (Lyons, 2016).

Notably, the prevalence of authoritarianism after conflict comes despite intense efforts by international actors to foster democracy. UN peacebuilding missions usually include electoral assistance, political party capacity-building, and civic education campaigns aimed at introducing or restoring multi-party electoral competition (Call and Cook, 2003; Call and Wyeth, 2008; Paris and Sisk, 2008). This push to democratize post-conflict states is reflective of a broader conviction within the UN that liberal democracy provides protection against future conflict and is thus central to sustainable peace (Joyner, 1999; Newman and Rich, 2004). In this way, international peacebuilding rest on a set of overtly normative foundations related to institutional reform and the desirability of democracy.

However, there are mixed findings on the success of these efforts and the scholarship in this area suffers from a number of limitations. Several authors find that democratization is more likely if a UN peacebuilding mission is deployed (Doyle and Sambanis, 2006; Joshi, 2013; Steinert and Grimm, 2015). Others are more skeptical about whether peacekeeping has any significant impact on post-conflict democracy, and Fortna (2008) finds no clear or positive relationship between peacekeeping and democratization.

Recently, scholars have also begun to note the potential side effects of international peacebuilding interventions, including the risk that missions can strengthen illiberal elites who leverage their role as guarantors of stability and peace to stall democratic reform (Autesserre, 2014: 147; Piccolino and Karlsrud, 2011). As Gowan (2015: 32) observes, 'the UN, having aspired to instill democracy and good governance in countries like the DRC and South Sudan, has ended up propping up unreliable and even autocratic leaders in the absence of better alternatives.'

In addition to these mixed findings, the scholarship in this area suffers from a problematic democracy bias that manifests itself in two ways. First, the theoretical discussions in this work focus on the causal mechanisms linking peacebuilding primarily with democratic rather than authoritarian governance (Doyle and Sambanis, 2006; Joshi, 2010; Matanock, 2017; Steinert and Grimm, 2015; Wantchekon, 2004). For example, in their critical review of the literature Fortna and Huang (2012) test the hypotheses that peacekeeping leads to greater democratization or has no effect, without explicitly discussing authoritarian outcomes. While the empirical strategy of many of these studies includes consideration of possible authoritarian outcomes (the dependent variable is often operationalized using a governance scale like Freedom House or Polity that includes values ranging from liberal democracy to closed authoritarianism), in practice the rhetorical and theoretical focus of these studies is restricted to democracy and democratization. Authoritarianism is implicitly or explicitly treated as the result of the absence of the

\footnotetext{
${ }^{3}$ We define authoritarianism as a regime in which the legislative and executive come to power through means other than free and fair elections (Svolik, 2012: 22).
} 
democratising causal mechanisms, rather than the presence of autocratizing ones.

Second, the scholarship in this area remains almost entirely divorced from the large and growing literature on authoritarianism (Brownlee, 2007; Gandhi, 2008; Svolik, 2012). This is unfortunate, as this literature contains sophisticated discussions of causal mechanisms through which authoritarian regimes emerge and endure that could be helpful in analysing the effect of peacebuilding. Some recent studies have used theories of authoritarianism to illustrate the dynamics of post-conflict regime change, but they have focused primarily on domestic politics and largely ignored the role of international peacebuilding missions (Huang, 2016; Lyons, 2016). In the following section, we address these two limitations, and set out the theoretical foundations for understanding the influence of international peacebuilding missions on authoritarian politics.

\section{Peacebuilders as Enablers of Authoritarianism}

To establish and maintain political power, autocrats must overcome a series of formidable challenges. They have to manage elite coalitions, suppress the threat of mass mobilization among a disaffected public, and avoid costly sanctions from international democracy promoters (Escriba-Folch and Wright, 2015; Kendall-Taylor and Frantz, 2014; Svolik, 2012). To do this, autocrats must have the political and economic capital to pursue a number of strategies that lie at the heart of authoritarian stability, including repression, patronage, propaganda, and the strategic use of institutions to mobilize supporters and co-opt opponents. Authoritarian resilience thus often rests on domestic factors such as the coercive and economic capacity of the state, the presence of certain political institutions (such as ruling parties), and the unifying power of regime legitimation strategies (Bellin, 2004; Dukalskis and Gerschewski, 2017; Levitsky and Way, 2013; Smith, 2005).

In recent years, scholars have increasingly sought to examine the ways in which international forces can influence these domestic dynamics of authoritarian survival (Burnell and Schlumberger, 2010; Tansey, 2016; von Soest, 2015). Much of this literature has focused on the role of powerful states such as Russia, China, and the United States in intentionally assisting autocratic incumbents to repress or co-opt their opponents (Bader, 2015; Tolstrup, 2013; Vanderhill, 2013; Yakouchyk, 2018). Others focus on passive rather than actor-driven international influences, such as diffusion effects (Ambrosio, 2010; Koesel and Bunce, 2013; Weyland, 2016), the autocracy-reinforcing influences of certain international linkages (Tansey et al., 2015), and the international balance of power (Boix, 2011). We place our study within a third category of analysis that focuses on the unintended consequences of actor-driven foreign interventions (Tansey, 2016: 45). International actors often intervene in foreign settings in ways that reinforce authoritarian rule despite rather than because of the objectives being pursued, for example through aid (Kono and Montinola, 2009), sanctions (Marinov, 2005), and democracy promotion itself (Carothers, 2006). Our analysis adds international peacebuilding to this list.

Indeed, despite their mandates to promote democracy, the policies that peacebuilders pursue often serve to benefit incumbent elites in ways that foster authoritarian rather than democratic forms of governance. We characterize international peacebuilders as 'enablers' of authoritarianism, where enabling entails a form of inadvertent external influence that facilitates authoritarian behavior by domestic elites. Enabling behavior exists on a spectrum from toleration to outright support, and its core characteristic is that it reduces the negative consequences of authoritarian actions for incumbent elites. We distinguish this from autocracy promotion because it is unintentional. That is, even if authoritarian outcomes can be foreseen, they do not constitute 
an explicit objective, and instead are the unhappy side effect of other actions. In the case of UN peacebuilding, the enablers in question do not actively seek to encourage authoritarian behavior, but through both action and inaction they reduce the negative repercussions usually associated with it. As we discuss below, these unintended consequences are the result of both the competing imperatives that the UN faces in post-conflict environments and tensions internal to the UNparticularly between its headquarters and missions in the field-about what to prioritize. As such, this work falls within the scholarship that has emphasized the unintended consequences of international aid and peacebuilding (Anderson, 1999; Aoi et al., 2007). This understanding of international enabling also distinguishes our approach from some of the critical writings on peacebuilding that trace the damaging effects of international intervention to an intentionally exploitative project where democracy promotion serves only as rhetorical window dressing (Chandler, 2006; Richmond, 2014).

Of course, the presence of a UN mission alone is not sufficient to contribute to authoritarian outcomes, and we expect that only certain forms of behavior will enable authoritarianism. Drawing on Tansey (2016), we identify two broad sets of causal mechanisms through which international peacebuilders can shape politics at the domestic level. The first concerns the ways in which peacebuilders enhance the capacity of regime incumbents, enabling them to project power, eliminate opponents, and secure their rule. The second concerns the flow of information, and how peacebuilders can send signals to domestic elites that lower the perceived costs of autocratic behaviour and broaden the opportunity structures for authoritarian rule.

\section{Material Mechanism: Enhancing Incumbent Capacity}

First, peacebuilders can directly enhance the capacity of host governments by providing institutional, security, and economic support that strengthens the regime. Indeed, capacity building is regularly at the heart of contemporary peacebuilding, including support to legislatures, political parties, the judiciary, and security forces (Lyons, 2004; Reynolds, 2010; Tansey, 2009). While capacity-building efforts often aim to promote democratic governance, they can contribute to authoritarian outcomes when elites use the state's newfound powers to pursue repressive policies (Levitsky and Way, 2010; Way, 2005). Manipulating elections requires administrative capacity and technical knowledge. Repressing rival elites and constraining the citizenry requires state institutions that have the capacity to monitor and control, often through coercion. Finally, stronger regimes are more likely to be able to deflect the pressures of international shaming or sanctions.

International peacebuilders thus face a dilemma, and must reconcile the competing imperatives of strengthening state actors and institutions and fostering democratic checks and balances that might challenge government authority. To date, scholars have found that UN missions have tended to resolve this tension in favor of the state, pursuing a top-down approach that often involves efforts to strengthen government elites at the expense of opposition forces (Autesserre, 2010: 91; Berdal and Zaum, 2013). ${ }^{4}$ This effect is partly due to the fact that the UN is an intergovernmental organization that would be hard-pressed to favor non-state actors over the state in any setting. It is also partly the result of the relationship between missions in the field and UN headquarters. There may be pressure from the latter to ensure stability, security, and

\footnotetext{
${ }^{4}$ Indeed, as an intergovernmental organization composed of member states, it would be difficult, and even unacceptable, for the UN to favor opposition or non-state actors above the state.
} 
measurable outputs, and missions may therefore be compelled to downgrade more normative objectives relating to democratization in favor of actions results delivery.

As a result, we expect that the UN's efforts will contribute to incumbent authoritarian capacity in a number of important ways, particularly related to institutional and security resources. The capacity-building functions and political reform agendas of international peacebuilding can enhance political structures in ways that strengthen and empower incumbent elites. The military contribution of peacebuilding can result in stronger domestic security forces, which benefit from direct training and exposure to professional international troops. Joint operations against rebel forces can also strengthen central government by reducing violent threats to its authority and altering the balance of power between incumbents and opposition forces. Furthermore, the infusion of economic resources that accompanies major international missions can expand the patronage opportunities for incumbents and facilitate the co-option of potential rivals. As a result, international peacebuilders can enable authoritarian rule even as they seek to promote peace and democracy.

Informational Mechanism: Signaling and the Opportunity Structures for Authoritarianism Second, and more indirectly, peacebuilders can send important signals and cues to incumbent elites about the likely consequences of authoritarian behavior. The strategies that autocrats use to survive in power can be risky and costly. For example, election fraud or violent crackdowns on civil and political liberties are often met with an international backlash that can harm the legitimacy and security of the regime (Donno, 2013; Van Der Vleuten and Hoffmann, 2010). Consequently, incumbents must estimate the likely international response to establish if they are operating in a permissive or constrained environment. Peacebuilders can influence this dynamic by providing crucial information about the nature of the international environment and thus shaping incumbent perceptions of the kind of opportunity structure they face (Gleditsch and Ruggeri, 2010).

Previous research has shown how external signals of support for incumbents can contribute to authoritarian outcomes by enhancing the perceived strength of the regime and lowering the perceived costs of repression (Tansey, 2016 Chapter 4; Tolstrup et al., 2018). International peacebuilders can engage in forms of toleration and tacit acceptance of authoritarian incumbents that provide crucial information about the permissive nature of the international environment. If incumbents operate in an international environment with a robust democracy enforcement regime, their opportunities for overt authoritarian behavior are narrow. By contrast, if the international environment is characterized by low levels of democratic conditionality and enforcement, opportunities are much broader.

International organizations often pursue weak or 'tame' forms of democracy advocacy due to institutional interests and incentives, including the need to maintain access to the target country (Bush, 2015). These dynamics are particularly apparent in the case of UN peacebuilding, where peacebuilding officials must balance their normative obligations with practical and operational ones and often face contradictory mandates (von Billerbeck, 2015). In normative terms, in addition to its commitment to democratization, the UN must be seen to respect sovereignty and the right to self-determination, and cannot impose its desired outcomes in the face of domestic opposition. In practical terms, the UN relies on the consent of the host government to deploy and remain in country. Furthermore, operational imperatives lead to an intense pressure on missions to achieve and maintain political stability-defined narrowly as the absence of a return to conflict-over and above other, potentially competing goals, such as democratization, the 
promotion of human rights, or justice. Much of this pressure can come from within the UN itself - from senior officials and member states at headquarters who push for quantifiable results and continued stability above normative objectives, thus making it difficult for missions to devise strong responses to authoritarian rule in the field, even if they want to. ${ }^{5}$

As a result of these conflicting obligations, peacebuilders sometimes fail to actively promote or defend the democratic norms in their mandates even in the face of blatant violations. The UN often works closely with national leaders who have shown little or no commitment to democracy but who wield sufficient political authority to be indispensable for any sustainable political settlement. When these actors breach democratic norms, the UN may ultimately refrain from robust criticism and continue to work with them for the sake of stability and retaining consent (Gowan 2015). These forms of toleration and tacit acceptance send important signals about the permissive nature of the international environment. Through policies of quiet acquiescence and lax conditionality, international peacebuilders thus expand the opportunity space that incumbent elites enjoy by lowering the likely negative consequences of authoritarian behavior.

\section{Research Design}

We use a single case study to lay the foundations for a broader comparative research agenda on the relationship between peacebuilding and authoritarianism, conducting a plausibility probe of our theorized causal mechanisms. Plausibility probes are 'preliminary studies on relatively untested theories and hypotheses' that can establish if further comparative exploration is warranted (George and Bennett, 2005: 75). We use DRC because it is a 'crucial case' where the evidence is particularly suitable for assessing causal claims (Eckstein, 1975; George and Bennett, 2005; Levy, 2008). More specifically, we argue that DRC is a 'most-likely crucial case,' where the independent variable is at a value that strongly predicts the outcome of interest.

In DRC, the UN has spearheaded a highly ambitious and intrusive international mission in a nondemocratic context, so if there is a causal relationship between peacebuilding and authoritarian outcomes it is likely to be evident here. The UN has been present in DRC since 1999 and its mission there has been among the UN's largest (at its peak, deploying over 20,000 civilian and military personnel). ${ }^{6}$ It is paradigmatic of the UN's shift to multi-dimensional peacekeeping, entailing a robust operation authorized to use force and mandated to undertake a vast array of tasks that has evolved and expanded over time, including security sector reform (SSR), the protection of civilians, and support for state capacity.

DRC also shows clear evidence in support of our argument for our dependent variable of interest. Freedom House has classified DRC as 'Not Free' in every year since the UN established a presence in the country in 1999, and the Polity index has consistently rated DRC as a nondemocracy. The Polity index also shows a sharp turn towards full-blown autocracy in recent

\footnotetext{
5 Bode and Karlsrud (2018) argue that the failure to implement norms can also result from divergent understandings of those norms. While their argument focuses on divergent understandings among member states, their point- that it is not the norm itself that is contested but that different actors have different understandings of it-is relevant to our argument. Few peacebuilders argue that democratization is an unworthy goal, but that commitment is eroded during implementation.

6 The UN mission in Congo is ongoing, so it is not possible to identify the final impact of the UN's presence. However, there is sufficient evidence in the years since the mission has been deployed to illustrate its impact to date on the nature and trajectory of the post-conflict regime in DRC.
} 
years, with an 8-point drop in its 21-point scale (from a steady score of 5 in the years after DRC's first post-conflict elections in 2006 to a score of -3 since 2016). ${ }^{7}$ DRC thus fits the profile of a most likely case that has high values on the dependent variable and that should, if our theoretical reasoning is correct, show clear evidence of our causal mechanisms. If we find no clear evidence of a link between UN peacebuilding and authoritarianism in DRC, a nondemocratic country playing host to an unusually authoritative UN mission, it would raise significant questions over the existence of any such relationship in general.

Our case study draws on a range of primary and secondary documents, including UN Security Council Resolutions and Reports, media reports, and policy and scholarly literature. As a secondary method, we also draw on original data from over 80 interviews conducted between 2009 and 2012 and between 2017 and 2018 with UN staff in MONUC, MONUSCO, and DPKO and Congolese political and civil society actors. We use these sources to identify how both UN action and inaction contributed to the institutional and coercive capacity of the regime and expanded Kabila's opportunity structures through lax enforcement and acquiescent behavior. In order to classify UN behavior in DRC as autocracy enabling rather than promoting, we examine the language and policies of the UN mission. We do not find the kind of rhetorical and operational commitment to authoritarianism usually associated with outright regime promotion. ${ }^{8}$ Furthermore, we do not argue that the UN was the sole or even principal driver of authoritarianism in DRC, nor do we advance a simplistic 'no peacebuilding, no authoritarianism' argument. Given its profile as a poor, conflict-affected country with limited history of democracy, it is likely that DRC would have consolidated an authoritarian regime had no UN mission existed. Rather, there are many paths to authoritarianism, and our aim is to illustrate the causal mechanisms through which international peacebuilders have contributed to the particular path to authoritarianism that has evolved in DRC.

\section{The UN and Authoritarianism in DRC}

The Mission de l'Organisation des Nations Unies (MONUC) was established in 1999. After 2003, when fighting formally concluded, the mission grew to have one of the most expansive mandates of all UN peacekeeping operations and became the largest mission in UN history (United Nations, n.d.; United Nations 2018b). In 2010, the mission was renamed the Mission de l'Organisation des Nations Unies pour la Stabilisation en RD Congo (MONUSCO).

Importantly, like many other UN peace operations, MONUC's and subsequently MONUSCO's mandate is deeply liberal in nature and emphasizes the importance of democratization. Security Council Resolution 2409 (2018), which renewed MONUSCO's mandate until 31 March 2019, calls on the mission to promote 'reconciliation and democratization' (United Nations, 2018c: 12) and its Political Affairs Division seeks to 'monitor and support democratisation' by building the capacity of state institutions and civil society (United Nations, 2018a). One of the earliest manifestations of this dedication to democratic principles was the enormous effort put into the 2006 presidential and legislative elections, which

\footnotetext{
${ }^{7}$ The Polity index runs from -10 to 10 , and only countries that score 6 or more are classified as democracies (Freedom House, 2018; Marshall et al., 2017).

${ }^{8}$ For more on the methodological challenges of empirically identifying intentional regime promotion, see Tansey 2016, 35-6.
} 
saw Kabila elected as the first post-transition president. The mission dedicated vast human, financial, and material resources towards the elections, including the training of over 250,000 polling agents (United Nations, 2007), and the international community contributed over US $\$ 400$ million (Carter Center, 2006: 18). While few claimed that the elections were a panacea for the country's formidable challenges, they were considered a critical step in bringing the transition period to an end and setting the country on the path towards democratic reform - and thus stability. The mission played a significantly smaller role in the 2011 elections, but the belief in their importance for continued peace and stability remained (United Nations, 2011c). In addition to elections, the mission has consistently emphasized the need for a vibrant opposition, civil society participation, free media, enfranchisement of the population, and transparency in political processes.

Despite the emphasis on democratization, the UN's efforts have failed to prevent the consolidation of an authoritarian regime in DRC. Almost immediately after his election in 2006, Kabila was accused of clamping down on the opposition, the press, and civil society (Autesserre 2010: 234; Matti, 2010: 57), and UN staff and other analysts began expressing alarm over the political direction of the country. One UN official described a serious 'contraction of [democratic] political space,' and Human Rights Watch warned that the government was 'heading in the direction of authoritarian rule' (The Economist, 2009). In a 2010 report, the International Crisis Group cautioned that ' $[\mathrm{t}]$ he danger of a return to authoritarianism is real' (2010: 23). Subsequently, the 2011 elections were widely condemned as fraudulent, and members of civil society, human rights activists, the media, and opposition politicians have encountered restrictions, repression, and abuse (Carter Center, 2011a; Carter Center, 2011b). More recently, presidential and legislative elections due in 2016 have been repeatedly postponed, and while the constitution prevents Kabila from running for a third term, he has made attempts to change the constitution and to delay the elections indefinitely.

Given the liberal bent of MONUC and MONUSCO and the many UN documents that mandate the UN to institutionalize international democratic standards in Congo, the consolidation of authoritarianism raises questions about the UN's ultimate impact on the ground. As mentioned, there is a growing literature on the unintended consequences of peace operations, some of which has focused on DRC in particular. However, these studies tend to examine levels of violence or consequences for civilians, rather than regime type. For example, Matti (2010) describes an authoritarian turn in DRC, but her focus is on foreign aid flows, neglecting the UN's influence. Autesserre (2010) discusses capacity building by the UN, but mentions authoritarian outcomes only in passing. In short, while several authors point to negative impacts of international involvement in DRC, none address authoritarianism as a distinct outcome worthy of theoretical exploration.

In the following sections, we examine how the UN contributed to authoritarianism in Congo through the two mechanisms described above: building incumbent capacity, including institutional and security capacity, and signaling a permissive environment for authoritarian behavior. Our analysis adds further precision to the two broad causal mechanisms we identified earlier, and illustrates a set of specific channels through which UN peacebuilding shaped authoritarianism in DRC.

Importantly, though peace operations are generally expected to 'work themselves out of a job' by putting in place institutions and capacity so that national actors can sustain post-conflict reforms themselves, and one might therefore expect the degree of authoritarian enabling to wane over time, we do not find evidence of this in DRC. The nature of the mission and its relationship 
with the government has evolved but the UN has maintained a consistently high level of involvement in DRC, with only minor decreases in personnel levels and alterations in the breadth of its mandate. We therefore find that the overall enabling process remains mostly constant across the course of the mission. However, we do identify variation in the ratio of informational to material enabling in response to particular challenges and opportunities. In particular, we see high levels of both informational and material enabling either in moments where there is a perceived opportunity within the UN to engender positive change-for example during elections - or in response to major security incidents or authoritarian moves by the regime. This remains the case throughout the life of the mission, and in fact, some of the most salient examples of enabling come later on in the UN's tenure in DRC. The precise type of enabling thus varies over time, but we do not observe a decreasing trend. Indeed, given the high profile of the mission in DRC, it is not surprising that both the pressure to deliver described above and the resulting risk of inadvertent enabling remain persistently elevated. The following sections outline how the two broad causal mechanisms worked in practice and tease out some of the key channels of international influence.

\section{Enhancing Incumbent Capacity}

As specified in its mandates, a number of the UN's activities in Congo were geared towards building the capacity of state political and security institutions. We find robust evidence that these efforts contributed to Kabila's capacity specifically and enabled his consolidation of political authority. The UN's support in terms of institutional capacity was most pronounced during the transition period from 2003-2006, because the relative weakness of domestic institutions led to a perception that the mission could have a strong impact and bring about tangible democratic change. In later years, when the regime faced new violent challenges, the UN also increased its support for the state's security institutions in ways that further solidified Kabila's authority.

\section{The UN and Institutional Capacity}

The UN's support to state institutions unwittingly facilitated the growth of authoritarianism in a number of ways. First, Congo's transition process was structured to ensure a strong presidency, including an unelected transitional government and the promulgation of a constitution that emphasized the executive, and thus higher levels of support to that office than to the opposition or weaker political parties. This was done largely because the international community saw the presidency as key to stability, and in the tense and uncertain conditions after fighting ended, the international community wanted to avoid a return to war. Its intentions were thus good-it did not purposely set out to facilitate authoritarianism, and instead took actions that were aimed at fulfilling parts of its mandate. However, while a strong presidency in and of itself is not necessarily authoritarian, it can create obstacles to democratization (Linz, 1990). In the case of DRC, by supporting the executive so heavily, the UN neglected to build other institutions that could act as counterweights to the president or that could render the exercise of executive power more transparent and equitable (Matti, 2010: 44, 53) and it gave the ruling party far greater visibility than other political parties and groups. As a result, the executive was in a better position to fend off challenges from and co-opt other elites, inhibit the opposition, and perform well in elections.

Second, the office of the executive was highly personalized in Kabila. Between 2001 and 2006, Kabila was MONUC's most important interlocutor, and the transitional arrangements were 
designed to prevent any overwhelming threats to him. The then Under-Secretary-General of Peacekeeping, Jean-Marie Guéhenno, describes how ' $[t]$ here was a fear, among key international actors, that [supporting opposition figures] could dangerously weaken the president and could lead to a resumption of war' (Guéhenno, 2015: 153). Indeed, the prioritization of the executive signaled that whoever occupied this office held a privileged position with the UN, granting him or her considerable leverage to resist the UN, and Kabila was clearly singled out for this role.

Third, capacity-building efforts during the transition focused on ensuring the passage of legislation relating to the elections and their subsequent organization, much more than on establishing a broader set of resilient institutions or building the capacity of a wide range of political actors. In this way, the few parties participating in the transitional government, and in particular Kabila's party, enjoyed far greater levels of input, material support, and publicity in the lead-up to the elections than parties outside the transition, giving them an advantage when it came to polling. Excluded political parties, in fact, became so disillusioned that they called for violent demonstrations to disrupt the transition (United Nations, 2005).

By focusing its capacity building efforts on the presidency and, to a lesser extent, mainstream political parties, the actions of the UN thus prioritized a balance of power that ensured continued stability over the quality of democracy and materially boosted Kabila's capacity to wield and retain political power in particular. These effects were largely unintended. As described, the UN's objectives were to ensure stability and free and fair elections, both of which were key components of its mandate. However, the personalization of the executive in Kabila signaled to him, first, that he was strongly backed by the UN, and, second, that the latter was prepared to accept lower levels of democratic fairness, transparency, and accountability in the interests of maintaining stability. It simultaneously signaled to Kabila's opponents that the need for a vibrant democratic opposition was not a priority for the UN. Finally, the UN's closeness to Kabila and tendency to view him as indispensable for holding together a fragile peace reduced its leverage over him, paving the way for ever-bolder authoritarian moves on his part.

\section{UN Use of Force and Security Capacity}

The UN also contributed to incumbent capacity through its support to state security services, as it was mandated to support the training and reform of both the Congolese armed forces and police (United Nations, 2008). While the mission made notoriously little headway with overall SSR (Onana and Taylor, 2008), it undertook a number of joint operations with the Congolese military, the Forces Armées de la République Démocratique du Congo (FARDC), and it later established the Force Intervention Brigade (FIB), a special unit of approximately 3,000 UN troops mandated to 'neutraliz[e]' non-state groups employing violence against civilians (United Nations 2013), in particular the M23 rebel group in eastern DRC. While the operations did lead to some reductions in rebel activity and, after the FIB was introduced, the effective elimination of M23, they also led to two significant unintended consequences: first, UN complicity in civilian harm caused by DRC's armed forces, and second, the strengthening of Kabila's increasingly personal political regime.

First, the FARDC has a long track record of abusing human rights, and the threat to civilians continued even after the joint operations were initiated. For example, Kimia II, an operation in 2009 targeted at the Forces Démocratiques de Libération $d u$ Rwanda (FDLR), a group composed of ex-génocidaires from Rwanda, made some progress in reducing the FDLR's numbers, but was harshly criticized for its 'catastrophic' humanitarian consequences, including massacres of civilians by government forces (United Nations, 2010b: 1). In response, MONUC 
introduced a conditionality policy, which required the mission to vet FARDC commanders before providing support and to withdraw support from units found to have committed abuses. However, the policy unsurprisingly soured relations with Kabila, and the FARDC found ways of circumventing it (United Nations 2010a). As a result, in the words of one UN official, the vetting process became "unworkable." Subsequently, the UN often appeared to ignore its own standards in order to maintain stable relations with Kabila, and it often backed down out of concern that if it pushed too hard, Congolese authorities would exclude the UN entirely from operations. ${ }^{10}$

This selective imposition of conditions, however, suggested that the UN was more anxious about the stability of Kabila's government than enforcing a zero-tolerance policy on human rights violations and that it would therefore accept a high degree of misconduct by the FARDC in order to maintain the status quo. And indeed, the UN's concerns in this regard were well founded: whenever the UN did withdraw support, it was met with strong rebukes from Kabila and threats that consent to the mission's presence would be withdrawn (Butty, 2015; Vircoulon, 2010). One UN official described an ongoing 'tension [between] mandates from the [Security] Council and different types of consent-partial, bleeding...'. ${ }^{11}$ Another remarked that the divergent views of headquarters and field staff further prevented robust, unified responses: while the view from New York 'revolve[s] around the proximity to the membership and the direct influence of troop, police, financial, and technology contributing countries...in the field what changes it is something goes boom or one political group leaves the process or you're unable to do the tasks that need to get done with the assets you have available on the ground. ${ }^{12}$ Accordingly, in the interests of being able to remain in country, the mission frequently tempered its insistence on normative standards and signaled a tolerance for repressive behavior. However, in the process, it lost considerable leverage over the government. As one analyst put it, ' $[\mathrm{b}] \mathrm{y}$ 2012, MONUSCO had effectively been battered into a corner by the government' (De Vries, 2015: 12).

Second, these joint operations, and the compromises they entailed, materially bolstered the stability of Kabila's increasingly authoritarian regime. As discussed, stable authoritarian rule depends in part on the material capacity of incumbent rulers (Bellin, 2004; Way, 2005), and the UN's cooperation with government forces in security operations provided a supplement to the state's coercive capacity. This, in turn, helped to weaken non-state groups challenging the authority of the state, thus shifting the domestic balance of power. One UN official recalled that when the UN established the FIB, 'we totally bought into the narrative of the Congolese...that...they're just victims of foreign armed groups,' and thus that the UN was correct to materially support the state against military threats against it. ${ }^{13}$ An important part of MONUC's mandate was of course the restoration of state authority; however, because the state was highly personalized, efforts to do so were tantamount to individual support to Kabila. As Guéhenno scornfully notes, the mission became a 'kind of gun for hire...President Kabila's own private military company,' enabling him to consolidate his grip on power (Paddon Rhoads, 2016: 151). Indeed, by explicitly tasking its troops with 'neutralizing' the government's rivals, the UN

\footnotetext{
${ }^{9}$ Interview with UN official, Geneva, January 2017.

${ }^{10}$ Interview with senior DPKO official, New York, December 2010. See also Vircoulon, 2010; de Vries, 2015.

${ }^{11}$ Interview with UN official, New York, February 2017.

12 Interview with UN official, New York, November 2017.

${ }^{13}$ Interview with UN official, New York, November 2017.
} 
sent a clear message about the strength of and its support for the regime (Nepstad, 2013), but one that appeared to run counter to the UN's normative commitment to democratization. Security was prioritized above political plurality, and thus, as one senior UN official put it, the UN became 'an unconditional agent of the central government.' 14

\section{Signaling a Permissive Environment}

In addition to enhancing Kabila's capacity, the mission also contributed to the intensification of authoritarian behavior by signaling that it was low-cost and offering tacit support for continued rule by Kabila. In particular, we highlight two specific arenas in which this informational effect was evident - namely, lax responses to electoral malpractice and to political repression. By repeatedly reacting weakly to repeated instances of electoral manipulation and violent repression in the years after 2006, MONUC and MONUSCO consistently created a permissive environment for the regime and signaled toleration for the regime's actions. Moreover, as the regime steadily became bolder and more overt in its authoritarian behavior, the UN remained mostly passive out of concern for the need to maintain consent to its presence.

\section{Lax Response To Electoral Malpractice}

One of the main ways in which authoritarian incumbents retain and consolidate their hold on power is through the manipulation of elections. At the same time, the successful conduct of elections was one of the UN's main mandated objectives in Congo and their failure was perceived to entail a significant risk to stability. While selecting government through free and fair competition is considered to be inherently democratic, the UN's desire to see the elections come off successfully meant that it was often willing to look the other way when fraudulent activities occurred. The UN thus signaled a permissive environment for Kabila during the elections in 2006 and 2011, as well as in the run-up to and aftermath of elections scheduled but never held in 2016.

The 2006 elections in DRC were considered a milestone in the peace process, and they saw Kabila elected president after a second round victory over his main opponent, Jean-Pierre Bemba. As described, MONUC played a major role in the conduct of the elections, and while it remained officially neutral, many staff privately admitted that the mission was biased in favor of Kabila, with one MONUC official noting that, 'the international community had picked Kabila as a winner even before he won. ${ }^{15}$ A Kabila presidency would enable the mission to continue its operations without having to build new working relationships with what would be a less experienced and arguably even weaker government. It would also make it easier for the mission to claim success in the organization of the elections and a smooth shift from the transitional government to the permanent one. Weiss notes that, 'Kabila owes his victory in no small part to...the longstanding support that he received from the international community,' including MONUC (Weiss, 2007: 151).

This pattern of tacit support for Kabila continued in the 2011 elections, which were characterized by considerably higher levels of politically-driven manipulation. Early in the year, the government amended the constitution to remove the second round requirement for the

\footnotetext{
${ }^{14}$ Interview with UN official, New York, November 2010.

${ }^{15}$ Interview with senior DPKO official, New York, December 2010.
} 
presidential elections, making it easier for the incumbent to win (International Crisis Group, 2011: i). The mission, by then renamed MONUSCO, was opposed to this step, but other than pressing heavily for the retention of the second round stipulation, did not sanction Kabila or his government, and it remained generally reluctant to criticize the electoral process. One UN official lamented that, 'you [didn't] find a single statement condemning this' and as a result, the UN 'create[d] the conditions for a president of [this] huge and diverse country...[to] be elected with 11 or $12 \%$ of the vote. ${ }^{16}$ This is largely because the UN's priority in this phase was to rebuild relations with the government, which had deteriorated significantly during Kabila's first term, as he increasingly invoked sovereignty and security threats as a way of excluding and obstructing the mission. Indeed, Kabila had begun discussing mission withdrawal almost as soon as he took office in 2006, causing serious concern within the UN. Accordingly, when the next round of elections came around, MONUSCO 'insist[ed] in public and private that they need[ed] to be "a neutral and supportive body and to avoid a formal judgmental role"' (Stearns 2011).

The mission also played a much smaller logistical and organizational role in 2011, and the elections were largely decried as fraudulent, with the Carter Center declaring that 'in essence, we do not know who actually won the presidential elections' (Carter Center, 2011b: 3). ${ }^{17}$ It is possible that Kabila would have won the elections with or without the UN's logistical support, as he had access to the entirety of state resources during his campaign; ${ }^{18}$ still, the UN displayed a preference for continuity and stability over any kind of democratic shake up, and its condemnation of the allegations of fraud was lukewarm. The mission 'note[d] with deep concern' the findings of international electoral observers and urged national authorities to investigate without delay, but stopped short of imposing sanctions or scaling back its interaction with Kabila (United Nations, 2011a; United Nations, 2011b). Later, in March 2012, when the UN Joint Human Rights Office published a report detailing killings, disappearances, and arbitrary detention during the electoral period by state security forces (MONUSCO and United Nations Office of the High Commissioner for Human Rights, 2012), the reaction of the mission remained relatively mild. In a statement, the then SRSG, Roger Meece, condemned the violations, but focused on the government's pledge to launch an investigation and 'the positive cooperation between MONUSCO and DRC military and civilian justice authorities' (United Nations, 2012).

Here, it is in the UN's lack of action in the face of Kabila's violations of electoral norms that we see a preference for him. The mission's failure to do more than condemn the irregularities in the election and urge investigation of abuses, while not an endorsement of these activities, constituted discretionary inaction in the interests of stability and maintaining good relations with the government. The absence of robust enforcement of the UN's own democratic norms thus signaled a permissive environment for Kabila, and widened the opportunity structures for authoritarianism. As Louise Arbour (2012), former High Commissioner for Human Rights, wrote in an open letter the UN Security Council at the time, MONUSCO failed to 'articulat[e] clear red lines for the credibility of the [electoral] process,' warning that this contributed to the 'potential

\footnotetext{
${ }^{16}$ Interview with UN official, New York, November 2017.

${ }^{17}$ A number of irregularities were reported in the elections, including problems with registration and voter lists, intimidation, and implausible voter turn-out rates of $100 \%$ in some areas.

${ }^{18}$ The Carter Center, which monitored the elections, declared that they 'lack[ed] credibility,' but added that it could not, on the basis of that, determine whether 'the final order of candidates [would] necessarily [have been] different.' (Carter Center, 2011a).
} 
for authoritarian drift.'

More recently, the build-up to the planned 2016 elections saw a continuation of the pattern of UN inaction in the face of worsening authoritarian practices by the Kabila regime, though there have been some notable exceptions. Kabila is constitutionally barred from standing for a third term, but he has made numerous efforts to prolong his tenure in power, including attempts to amend the constitution and to eliminate his main electoral challengers. These actions have been met with widespread outcry and have triggered, unusually for Congo, large public demonstrations; the government, however, has responded with violent repression, resulting in scores of deaths (The Guardian, 2015; Human Rights Watch, 2015).

The UN's reaction to these events has been mixed. Privately, it has exerted strong pressure on Kabila and compelled him to drop some of his attempts to alter legislation or the constitution. In addition, the SRSG from 2015-18, Maman Sidikou, made robust statements condemning election-related human rights violations against opposition members, civil society, and the media. Yet at the same time, the mission has continued to interact with the government as usual (UN News Centre, 2016). Like in 2011, mission personnel worried that being too outspoken would damage relations with the government, resulting in a withdrawal of consent and the expulsion of the mission, and potentially the collapse of the many years of work and resources they have put into Congo (Stimson Center and Better World Campaign, 2016: 8). Here again then, UN inaction and selective enforcement of democratic standards have sent important informational signals to the regime that it can get away with authoritarian behavior. For some, this passive approach has made the UN complicit in DRC's authoritarian regime. As one UN official pointed out, the mission's failure to increase pressure for elections on the government has made the UN 'part of... upholding... a fiction." ${ }^{19}$

\section{Lax Response To Repression}

While the UN's support for Kabila has been most visible during the electoral periods, the UN's behavior between the elections has equally demonstrated a reluctance to press him too hard for fear of instability or withdrawal of consent, again signaling the permissiveness of the environment. Indeed, though the UN has made efforts to deter Kabila from particularly egregious actions, the general trend of ignoring Kabila's authoritarian practices has continued whenever he was faced with challenges to his rule from political elites or the public. There are two ways in which the UN has abetted Kabila's mounting authoritarianism: first, its interaction with the opposition has fallen dramatically, and second, it has reacted mildly to or ignored violent repression of the opposition and others.

Once the transition ended in 2006, MONUC interacted markedly less with the opposition. This is at least partly explained by the institutional constraints of an intergovernmental organization, which cannot circumvent an elected sovereign government and member state, but it subsequently bolstered the regime's ability to repress the opposition. As Gambino describes, the international community, including MONUC, 'adopted the collective attitude after elections that, since the post-elections state was now legitimate and sovereign, it was fully in charge and donors could only respond to state-initiated requests' (Gambino, 2011:7). However, because the UN had helped to entrench that state as one personalized in Kabila and had neglected to strengthen institutions, deference to the state was problematic. One UN official asserted that when MONUC

\footnotetext{
${ }^{19}$ Interview with UN official, New York, November 2017.
} 
first deployed, it 'had a very clear purpose,' but 'since the elections in 2006...the goalposts have been slipping... and there's an identity crisis [about] what it is that they're actually trying to achieve.' Indeed, while the UN remained in principle dedicated to the creation of a vibrant political life in Congo, one in which opposition groups, civil society, and others could participate, challenge, and hold office, the mission has become less forceful in its insistence on normative standards, and has instead increasingly acceded to Kabila's demands. In so doing, however, it has facilitated Kabila's ability to eliminate, repress, or intimidate these groups, and reduced its ability to sanction him when he has done so.

Indeed, as soon as he was sworn in in December 2006, that is precisely what Kabila did. Allegations of vote-buying in 2007 gubernatorial elections that installed Kabila supporters in nearly all provinces provoked no reaction or sanction from MONUC, which remained keen to continue characterizing the end of the transition as a success (Congo Research Group, 2009; International Crisis Group, 2010: 8-9; International Crisis Group, 2007: 9-10). Subsequently, Kabila launched 'brutal and sudden' military offensives against Bemba and his guards in Kinshasa in March 2007, which saw hundreds of civilians killed (Human Rights Watch, 2008: 3). While the UN tracked and monitored abuses, helped civilians to safety, and provided protection for MLC guards, it also delayed publishing reports about its investigations into what happened and avoided condemning the government specifically, instead denouncing violence on all sides (Human Rights Watch, 2008: 91-92). This is both because the government was still relatively new and the UN wanted to ensure its stability and because the UN needed to reconfigure its own post-elections role in the country and so could not afford to criticize the government lest it withdraw consent for the mission. Eventually, when Bemba fled the country in April 2007, there was 'almost no international reaction' (Guéhenno, 2015: 157).

Similarly, when Bundu Dia Kongo (BDK), a politico-religious group based in Bas-Congo Province, demonstrated against electoral fraud in gubernatorial elections in 2007, their protests were met with a swift and harsh response by state security agents, with over 100 BDK members killed (Tull, 2010: 651). Violence broke out again in March 2008, and a major operation by the Police Nationale Congolaise (PNC, Congolese National Police) resulted in at least 100 BDK deaths, as well as arbitrary detentions, torture, and summary executions. ${ }^{20}$ While MONUC did conduct an investigation into the incidents, its condemnation remained mild and excluded penalizing the government for not holding perpetrators to account (Gambino, 2011: 7).

Again, in order to avoid a return to war and lose consent to its deployment, the UN 'has remained mostly silent' (International Crisis Group, 2010: 1) - but that silence has spoken volumes about the nature of the international environment in which the Congolese regime operates and the low costs of authoritarian behavior. As one senior UN official noted, Kabila 'crushed Bemba, bought the provincial parliaments, and weakened parliament, all without much international protest. ${ }^{21}$ In response to separate instances of serious violent repression, the UN thus offered little robust response and signaled once again that the regime can get away with authoritarian practices without meaningful censure.

\footnotetext{
${ }^{20}$ Estimates of the death toll vary, with the official government figure at 27, the MONUC investigation at 100, and HRW at 200 (Human Rights Watch, 2008: 77; MONUC Human Rights Division and Office of the United Nations High Commissioner for Human Rights, 2008: 4).

${ }^{21}$ Interview with senior DPKO official, New York, December 2010.
} 


\section{Conclusion}

International peacebuilders face a range of competing objectives when deployed to post-conflict countries. In an era of ambitious multidimensional peacebuilding, they must strive not only to maintain peace and prevent a resumption of hostilities, but also to build state capacity, foster societal reconciliation, and promote democratic development. These goals are difficult to achieve in tandem, as the activities used to promote one can undermine those used to achieve another. Furthermore, UN peacebuilders must work within the organization's practical and operational constraints, which emphasize host country consent and the delivery of measureable indicators of success and sometimes entail differences between headquarters and missions in the field.

As a result of these competing pressures, international peacebuilders must at times prioritize some goals and relegate others. In this paper, we have shown that it is often the promotion of democracy that is deemed dispensable when it threatens security and stability or working relationships with incumbent elites. In DRC, the UN has inadvertently enabled authoritarian practices in two ways: by supplementing state capacities and by creating a permissive environment for non-democratic rule. MONUC and later MONUSCO boosted the material and coercive capacity of the regime and contributed to the personalization of politics by investing heavily in its relationship with an individual leader rather than a wider spectrum of actors. Furthermore, in the wake of flagrant breaches of democratic norms, the UN signaled its tolerance for authoritarianism through muted criticism and continued cooperation with the regime.

Our study thus highlights the limitations of the current scholarship on international peacebuilding, and points the way to a new research agenda on the international dimensions of authoritarian rule. While the literature on international peacebuilding has often noted the limited capacity of international missions to successfully consolidate democracy, it has paid much less attention to the mechanisms through which they contribute to the pillars of authoritarian stability. Our analysis identifies a set of causal mechanisms that can be used as a framework for comparative analysis of the relationship between peacebuilding and authoritarianism across diverse settings. In addition, our analysis suggests a set of conditions under which these causal mechanisms are more or less likely to operate. In particular, in large missions that have a mandate to use force to protect and strengthen the state, the UN may be more likely to provide the types of material support we outline above. Furthermore, where mission success is perceived as crucial to the UN's wider reputation, as we contend was the case in Congo, both UN headquarters and missions in the field may be more likely to offer the tacit support to incumbent elites that preserves good relations but nonetheless expands the opportunity space for authoritarianism.

As shown, the case of Congo demonstrated these key characteristics, and though the exact constellation of material and informational enabling varied over time, the overall effect remained remarkably persistent. While DRC is, as noted, an extreme case, we argue that our mechanisms can shed light on other cases that share similarities with DRC, such as wide-ranging political and military mandates, large troop deployments, lengthy missions, and the use of force. For example, Cambodia, Haiti, South Sudan, and the Central African Republic have all hosted large-scale UN peacebuilding missions and struggled to introduce or consolidate stable democratic regimes. At the same time, the missions in these countries also exhibit variations in their levels of political authority domestically, including, crucially, in the extent to which the use of force has been authorized. Cross-case comparisons could thus tease out the ways in which each mission's mandate shaped its propensity to contribute to non-democratic outcomes. Comparative research 
should also analyze the divergent experiences of countries that have experienced relatively more success with democratic development during and after UN peacebuilding, such as Mozambique, Liberia, and Timor-Leste. Our findings provide a rigorous challenge to existing assumptions and theoretical biases in the scholarship in this area, and further comparative research will help to establish the conditions under which different types of UN mission may enable authoritarianism or democracy in different ways in diverse settings.

Ambrosio T (2010) Constructing a framework of authoritarian diffusion: concepts, dynamics, and future research. International Studies Perspectives 11(4): 375-392.

Anderson MB (1999) Do No Harm: How Aid Can Support Peace--or War. Lynne Rienner Publishers.

Aoi C, Coning C de and Thakur R (eds) (2007) Unintended Consequences of Peacekeeping Operations. Tokyo, : New York: UN Distributed Titles.

Arbour, L. (2012) Open Letter to the United Nations Security Council on the Situation in the Democratic Republic of Congo. Brussels: International Crisis Group.

Art D (2012) What Do We Know About Authoritarianism After Ten Years? Comparative Politics 44(3): 351-373.

Autesserre S (2010) The trouble with the Congo: Local violence and the failure of international peacebuilding. Cambridge University Press.

Autesserre S (2014) Peaceland: Conflict Resolution and the Everyday Politics of International Intervention. Cambridge University Press.

Bader J (2015) China's Foreign Relations and the Survival of Autocracies. London: Routledge.

Bellin E (2004) The robustness of authoritarianism in the Middle East: exceptionalism in comparative perspective. Comparative Politics 36(2): 139-157.

Berdal M and Zaum D (eds) (2013) Political Economy of Statebuilding. Routledge.

Bermeo N (2003) What the Democratization Literature Says —or Doesn't Say_About Postwar Democratization. Global Governance 9: 159-177.

Bernhard M, Reenock C and Nordstrom T (2003) Economic Performance And Survival In New Democracies Is There A Honeymoon Effect? Comparative Political Studies 36: 404-431.

Bode I and Karlsrud J (2018) Implementation in Practice: The Use of Force to Protect Civilians in United Nations Peacekeeping. European Journal of International Relations.

Boix C (2011) Democracy, development, and the international system. American Political Science Review 105(4): 809-28. 
Brownlee J (2007) Authoritarianism in an Age of Democratization. Cambridge: Cambridge University Press.

Burnell P and Schlumberger O (2010) Promoting Democracy - Promoting Autocracy? International politics and national political regimes. Contemporary Politics 16(1): 1-15.

Bush SS (2015) The Taming of Democracy Assistance: Why Democracy Promotion Does Not Confront Dictators. Cambridge: Cambridge University Press.

Butty J (2015) Congo official: DRC will not accept UN ‘decolonization'. Voice of America 29.

Call C and Wyeth VH (eds) (2008) Building States to Build Peace. Boulder: Lynne Rienner Publishers.

Call CT and Cook SE (2003) On democratization and peacebuilding. Global Governance 9: 233-246.

Carothers T (2006) The backlash against democracy promotion. Foreign Affairs 85(2): 55-68.

Carter Center (2006) International Election Observation Mission to Democratic Republic of Congo 2006: Presidential and Legislative Elections: Final Report.

Carter Center (2011a) Carter Center: DRC Presidential Election Results Lack Credibility. https://www.cartercenter.org/news/pr/drc-121011.html (accessed 15 July 2018).

Carter Center (2011b) Presidential and Legislative Elections in the Democratic Republic of the Congo: Final Report.

Chandler D (2006) Empire in Denial: The Politics of State-Building. London; Ann Arbor, MI: Pluto Press.

Congo Research Group (2009) Is this the death of the MLC? In Congo Siasa: A Blog on Congo, Its Politics and Tribulations edited by Jason K. Stearns http://congoresearchgroup.org/isthis-death-of-mlc/ (accessed 15 July 2018).

De Vries H (2015) Going around in circles: The challenges of peacekeeping and stabilization in the Democratic Republic of the Congo. Clingendael Institute.

Donno D (2013) Defending democratic norms: international actors and the politics of electoral misconduct. Oxford: Oxford University Press.

Doyle MW and Sambanis N (2006) Making War and Building Peace: United Nations Peace Operations. Princeton University Press.

Dukalskis A and Gerschewski J (2017) What autocracies say (and what citizens hear): Proposing four mechanisms of autocratic legitimation. Contemporary Politics 23(3). 
Eckstein H (1975) Case studies and theory in political science. In: Handbook of political science. Political science: Scope and theory. Reading, MA: Addison-Wesley.

The Economist (2009) Congo's Constitution: Democracy Under Threat.

Escriba-Folch A and Wright J (2015) Foreign Pressure and the Politics of Authoritarian Survival. Oxford: Oxford University Press.

Fish MS and Kroenig M (2006) Diversity, Conflict and Democracy: Some Evidence from Eurasia and East Europe. Democratization 13: 828-842.

Fortna VP (2008) Peacekeeping and democratization. In: Jarstad AK and Sisk TD (eds) From war to democracy: Dilemmas of peacebuilding.

Fortna VP and Huang R (2012) Democratization after Civil War: A Brush-Clearing Exercise. International Studies Quarterly 56(4): 801-808.

Freedom House (2018) Freedom in the World. Available at: https://freedomhouse.org/report/freedom-world/freedom-world-2018 (accessed 12 July 2018).

Gambino, T. (2011) Democratic Republic of the Congo. World Development Report 2011 Background Case Study. Washington, DC: World Bank Group.

Gandhi J (2008) Political institutions under dictatorship. New York, NY: Cambridge University Press.

George AL and Bennett A (2005) Case studies and theory development in the social sciences. Cambridge, MA: MIT Press.

Gleditsch KS and Ruggeri A (2010) Political opportunity structures, democracy, and civil war. Journal of Peace Research 47: 299-310.

Gowan R (2015) The Peacekeeping Quagmire. Georgetown Journal of International Affairs.

The Guardian (2015) Senegal leader Macky Sall offers to reduce presidential term as "example to Africa." https://www.theguardian.com/world/2015/mar/18/senegal-leader-macky-salloffers-to-reduce-presidential-term-as-example-to-africa (accessed 15 July 2018)

Guéhenno J-M (2015) The Fog of Peace: A Memoir of International Peacekeeping in the 21st Century. Brookings Institution Press.

Huang R (2016) The Wartime Origins of Democratization: Civil War, Rebel Governance, and Political Regimes. Cambridge University Press.

Human Rights Watch (2008) “We Will Crush You”: The Restriction of Political Space in the Democratic Republic of Congo. New York: Human Rights Watch. 
Human Rights Watch (2015) DR Congo: Mass Arrests of Activists. https://www.hrw.org/news/2015/03/18/dr-congo-mass-arrests-activists (accessed 15 July 2018).

Jarstad AK and Sisk TD (2008) From war to democracy: dilemmas of peacebuilding. Cambridge university press.

International Crisis Group (2007) Congo: Consolidating the Peace. Africa Report No. 128. Nairobi/Brussels: International Crisis Group.

International Crisis Group (2010) Congo: A Stalled Democratic Agenda. Africa Briefing No. 73. Nairobi/Brussels: International Crisis Group.

International Crisis Group (2011) Congo: The Electoral Dilemma. Africa Report No. 175. Kinshasa/Nairobi/Brussels: International Crisis Group.

Joshi M (2010) Post-civil war democratization: promotion of democracy in post-civil war states, 1946-2005. Democratization 17(5): 826-855.

Joshi M (2013) United Nations Peacekeeping, Democratic Process, and the Durability of Peace after Civil Wars. International Studies Perspectives 14(3): 362-382.

Joyner CC (1999) The United Nations and Democracy. Global Governance 5: 333-357.

Kendall-Taylor A and Frantz E (2014) How autocracies fall. The Washington Quarterly 37(1): $35-47$.

Koesel KJ and Bunce VJ (2013) Diffusion-Proofing: Russian and Chinese Responses to Waves of Popular Mobilizations against Authoritarian Rulers. Perspectives on Politics 11(3): 753-768.

Kono DY and Montinola GR (2009) Does Foreign Aid Support Autocrats, Democrats, or Both? The Journal of Politics 71(02): 704-718.

Levitsky S and Way LA (2010) Competitive authoritarianism: hybrid regimes after the cold war. Cambridge: Cambridge University Press.

Levitsky S and Way LA (2013) The Durability of Revolutionary Regimes. Journal of Democracy 24(3): 5-17.

Levy JS (2008) Case studies: Types, designs, and logics of inference. Conflict management and peace science 25(1): 1-18.

Linz JJ (1990) The Perils of Presidentialism. Journal of Democracy 1(1): 51-69.

Lyons T (2004) Post-conflict elections and the process of demilitarizing politics: the role of electoral administration. Democratization 11:36-62. 
Lyons T (2016) The Importance of Winning: Victorious Insurgent Groups and Authoritarian Politics. Comparative Politics 48(2): 167-184.

Marinov N (2005) Do Economic Sanctions Destabilize Country Leaders? American Journal of Political Science 49(3): 564-576.

Marshall MG, Gurr TR and Jaggers K (2017) Polity IV Project. Political Regime Characteristics and Transitions, 1800-2016. Dataset Users' Manual. Center for Systemic Peace. Available at: http://www.systemicpeace.org/inscr/p4manualv2015.pdf (accessed 13 June 2017).

Matanock AM (2017) Electing Peace: From Civil Conflict to Political Participation. Cambridge University Press.

Matti SA (2010) The Democratic Republic of the Congo? Corruption, Patronage, and Competitive Authoritarianism in the DRC. Africa Today 56(4): 42-61.

MONUC and Office of the United Nations High Commissioner for Human Rights (2008) Special Inquiry into the Bas Congo Events of February and March 2008. http://www.refworld.org/docid/48624eae2.html (accessed 19 July 2018).

MONUSCO and United Nations Office of the High Commissioner for Human Rights (2012) Report of the United Nations Joint Human Rights Office on Serious Human Rights Violations Committed by Members of the Congolese Defense and Security Forces in Kinshasa in the Democratic Republic of the Congo between 26 November and 25 December 2011. https://www.ohchr.org/Documents/Countries/CD/ReportDRC_26Nov_25Dec2011_en.pd f (accessed 19 July 2018).

Nepstad SE (2013) Mutiny and nonviolence in the Arab Spring: Exploring military defections and loyalty in Egypt, Bahrain, and Syria. Journal of Peace Research 50(3): 337-349.

Newman E and Rich R (2004) The UN role in promoting democracy: Between ideals and reality. New York, NY: United Nations Publications.

Onana R and Taylor H (2008) MONUC and SSR in the Democratic Republic of Congo. International Peacekeeping 15(4): 501-516.

Paddon Rhoads E (2016) Taking sides in peacekeeping: impartiality and the future of the United Nations. Oxford University Press.

Paris R and Sisk TD (eds) (2008) The Dilemmas of Statebuilding: Confronting the Contradictions of Postwar Peace Operations. London; New York: Routledge.

Piccolino G and Karlsrud J (2011) Withering consent, but mutual dependency: UN peace operations and African assertiveness. Conflict, Security \& Development 11(4): 447-471. 
Reilly B (2001) Democracy in divided societies: Electoral engineering for conflict management. Cambridge: Cambridge University Press.

Reynolds A (2010) Designing Democracy in a Dangerous World. Oxford: OUP Oxford.

Richmond O (2014) Failed Statebuilding: Intervention, the State, and the Dynamics of Peace Formation. New Haven: Yale University Press.

Sambanis N (2000) Partition as a Solution to Ethnic War: An Empirical Critique of the Theoretical Literature. World Politics 52(04): 437-483.

Smith B (2005) Life of the party: The origins of regime breakdown and persistence under singleparty rule. World Politics 57: 421-451.

Stearns, J. (2011) Donors and elections in the Congo. Congo Siasa: A Blog on Congo, Its Politics and Tribulations. http://congosiasa.blogspot.co.uk/2011/09/donors-and-elections-incongo.html (accessed 15 July 2018).

Stearns J. (2017) The Democratic Republic of the Congo: An Elusive Peace. In: War and Peace in Africa's Great Lakes Region. Palgrave Macmillan, pp. 33-47.

Steinert JI and Grimm S (2015) Too good to be true? United Nations peacebuilding and the democratization of war-torn states. Conflict Management and Peace Science 32(5): 513535.

Stimson Center and Better World Campaign (2016) Challenges and the Path Forward for MONUSCO.

Svolik MW (2012) The Politics of Authoritarian Rule. Cambridge: Cambridge University Press.

Tansey O (2009) Regime-Building: Democratization and International Administration: Democratization and International Administration. Oxford: Oxford University Press.

Tansey O (2016) The International Politics of Authoritarian Rule. Oxford: Oxford University Press.

Tansey O, Koehler K and Schmotz A (2015) Ties to the Rest: Autocratic Linkages and Regime Survival. Unpublished paper, King’s College London.

Toft MD (2010) Ending Civil Wars: A Case for Rebel Victory? International Security 34(4): 7 36.

Tolstrup J (2013) Russia vs. the EU: External Actors in Competition for Influence in Post-Soviet States. Boulder, CO: Lynne Rienner Publishers.

Tolstrup J, Seeberg MA and Glavind JG (2018) Signals of Support From Great Power Patrons and the Use of Repression During Nonviolent Protests. Comparative Political Studies: Online First. 
United Nations (2005). Eighteenth report of the Secretary-General on the United Nations Organization Mission in the Democratic Republic of the Congo. S/2005/506.

United Nations (2007) 2006: A year of hope for the Congolese people. In United Nations Peace Operations: Year in Review 2006. New York: United Nations Department of Public Information. http://www.un.org/ar/peacekeeping/publications/yir/2006/congo.htm (accessed 15 July 2018).

United Nations (2008) Security Council Resolution 1856. S/RES/1856.

United Nations (2010a) Report of the Secretary-General on the United Nations Organization Stabilization Mission in the Democratic Republic of Congo. S/2010/512.

United Nations (2010b) Report of the Special Rapporteur on extrajudicial, summary or arbitrary executions, Philip Alston: Addendum, A/HRC/14/24/Add.3.

United Nations (2011a) MONUSCO: MONUSCO Calls on INEC to Address Electoral Observer Missions' Concerns. https://monusco.unmissions.org/en/monusco-calls-inec-addresselectoral-observer-missions'-concerns (accessed 15 July 2018);

United Nations (2011b) MONUSCO: Presidential and National Legislative Elections: Roger Meece Appeals for Calm. https://monusco.unmissions.org/en/presidential-and-nationallegislative-elections-roger-meece-appeals-calm (accessed 15 July 2018).

United Nations (2011c) Security Council Resolution 1991. S/RES/1991.

United Nations (2012) MONUSCO: Human Rights Violations During DRC General Elections. https://monusco.unmissions.org/en/human-rights-violations-during-drc-general-elections (accessed 15 July 2018).

United Nations (2013) Security Council Resolution 2098. S/RES/2098.

United Nations (2017) Security Council Resolution 2348. S/RES/2348.

United Nations (2018a) MONUSCO: Political Affairs Activities. http://monusco.unmissions.org/en/political-affairs-activities (accessed 11 July 2018).

United Nations (2018b) Peacekeeping Operations Fact Sheet, Department of Peacekeeping Operations. https://peacekeeping.un.org/sites/default/files/pk_factsheet_05_18_eng_0.pdf (accessed 15 July 2018).

United Nations (2018c) Security Council Resolutions 2409. S/RES/2409.

United Nations (n.d.). MONUC Facts and Figures, Department of Peacekeeping Operations. https://peacekeeping.un.org/sites/default/files/past/monuc/facts.shtml (accessed 15 July 2018). 
UN News Centre (2010) DR Congo: UN support for army's new anti-rebel offensive tied to protecting civilians.

http://www.un.org/apps/news/story.asp?NewsID=33422\#.WWy10DPMzGI (accessed 15 July 2018).

UN News Centre (2016) 'Very real risk of violence looms over DR Congo elections, senior UN official warns. http://www.un.org/apps/news/story.asp?NewsID=53000\#.V9k_cjvarGI (accessed 15 July 2018).

Van Der Vleuten A and Hoffmann AR (2010) Explaining the Enforcement of Democracy by Regional Organizations: Comparing EU, Mercosur and SADC. JCMS: Journal of Common Market Studies 48(3): 737-758.

Vanderhill R (2013) Promoting Authoritarianism Abroad. Boulder, CO: Lynne Rienner Publishers.

Vircoulon T (2010) After MONUC, should MONUSCO continue to support Congolese military campaigns? International Crisis Group 19.

von Billerbeck S (2015) Local Ownership and UN Peacebuilding: Discourse Versus Operationalization. Global Governance: A Review of Multilateralism and International Organizations 21(2): 299-315.

von Billerbeck S (2016) Whose Peace? Local Ownership and United Nations Peacekeeping. Oxford: Oxford University Press.

von Soest C (2015) Democracy prevention: The international collaboration of authoritarian regimes. European Journal of Political Research 54(4): 623-638.

Wantchekon L (2004) The paradox of "warlord" democracy: A theoretical investigation. American political science review 98(1): 17-33.

Way LA (2005) Authoritarian state building and the sources of regime competitiveness in the fourth wave: the cases of Belarus, Moldova, Russia, and Ukraine. World Politics 57: $231-261$.

Weiss HF (2007) Voting for Change in the DRC. Journal of Democracy 18(2): 138-151.

Weyland K (2016) Crafting Counterrevolution: How Reactionaries Learned to Combat Change in 1848. American Political Science Review 110(02): 215-231.

Yakouchyk K (2018) Beyond Autocracy Promotion: A Review. Political Studies Review: 1478929918774976.

Zürcher C, Manning C, Evenson K, et al. (2013) Costly Democracy: Peacebuilding and Democratization After War. Stanford University Press. 
